\title{
The effect of role ambiguity and role conflict on job performance in the hotel industry: the mediating effect of job satisfaction
}

\section{O efeito da relação entre ambiguidade e conflito de funções na indústria hoteleira: o efeito mediador da satisfação do trabalho}

\section{Engin Unguren}

University of Alanya Aladdin Keykubat, Faculty of Economics and Administrative Sciences, Turkey, engin.unguren@alanya.edu.tr

\author{
Serdar Arslan
}

University of Alanya Aladdin Keykubat, Faculty of Economics and Administrative Sciences, Turkey, serdar.arslan@alanya.edu.tr

Received: 02.09.2020; Revisions required: 25.10.2020; Accepted: 16.11.2020

\begin{abstract}
Accommodation businesses are stressful workplaces due to their dynamic and demanding work environment. Role ambiguity and role conflict are major stress factors for hotel employees, causing low levels of satisfaction and performance and high levels of turnover. The main purpose of this study was to explore the mediating effect of job satisfaction on the relationship between role conflict, role ambiguity, and job performance. The data was collected through fully structured questionnaires from employees working in 3, 4 and 5 star hotels in Alanya, one of the leading tourism destinations in Turkey. The data was analyzed via structural equation modeling. The results revealed that both role conflict and role ambiguity have direct negative influences on job performance and job satisfaction for hotel employees. Moreover, it was also proved that job satisfaction mediates the effect of role conflict and role ambiguity on job performance. In line with the findings, theoretical and managerial implications, contributions, limitations, and future research directions were discussed. It was implied that role stress factors must be addressed seriously by hotel managers in order to increase job performance.
\end{abstract}

Keywords: Stress factors, role ambiguity, role conflict, job satisfaction, job performance, hospitality sector.

\section{Resumo}

As empresas de alojamento são locais de trabalho stressantes devido ao seu ambiente de trabalho dinâmico e exigente. Ambiguidade de funções e conflito de funções são fatores de stresse importantes para as empresas hoteleiras, causando baixos níveis de satisfação, desempenho e altos níveis de rotatividade. O principal objectivo deste estudo foi explorar o efeito mediador da satisfação profissional na relação entre conflito de funções, ambiguidade de funções e desempenho. Os dados foram recolhidos por questionários estruturados aos funcionários que trabalham em hotéis de 4 e 5 estrelas em Alanya, um dos principais destinos turísticos na Turquia. Os dados foram analisados através de modelagem de equações estruturais. Os resultados revelaram que a satisfação do trabalho mediou totalmente a relação entre a ambiguidade da função e o conflito da função e o desempenho do trabalho. De acordo com os resultados, as implicações práticas dos resultados, contribuições, limitações e futuras linhas de investigação foram discutidas.

Palavras-chave: Fatores de stresse, ambiguidade de funções, conflito de funções, satisfação no trabalho, desempenho no trabalho, setor hoteleiro.

\section{Introduction}

Accommodation businesses are stressful workplaces due to their dynamic and demanding work environment with a culturally diverse customer segment (Choi, Mohammad, \& Kima, 2019; Tiyce, Hing, Cairncross \& Breen, 2013; Chiang, Birtch \& Kwan, 2010). The hospitality industry, by definition, is characterized by high levels of customer contact. Customercontact service employees play a boundary-spanning role where they interact with many individuals from inside and outside of their organization (Gill, Flaschner, \& Shachar, 2006). On top of that, customer expectations have increased dramatically in recent years in parallel with the increasing competition between accommodation businesses. As a result, businesses have higher expectations of their employees. Employees, on the other hand, must overcome ambiguities when they answer changing and conflicting demands of different customer groups. Ambiguity in how to perform a certain task is one of the main causes of work stress (Kim, Murrmann, \& Lee, 2009; CahayaSanthi \& Piartrini, 2020).

It is essential to lower stress in the workplace to an acceptable level in order to increase productivity, motivation, and commitment among employees. This is possible only with a comprehensive understanding of stress factors and having solid precautions against them (Altintas \& Turanligil, 2018). Past research shows that the main stress factors specific to accommodation businesses are long and exhausting hours of work, low salaries, seasonal employment, job insecurity, high turnover rates, and limited career opportunities (Pizam \& Thornburg, 2000; Jogaratnam \& Buchanan, 2004; Cleveland, O’Neill , Himelright, Harrison \& Crouter, 2007; Hwang, Lee, Park, Chang, \& Kim, 2014; Chuang \& Lei, 2011; Tiyce et al., 2013; Wen, Zhou, Hu, \& Zhang, 2020). It also seems that role ambiguity and role conflict are among the most important antecedents of work stress (Kahn, Wolfe, Quinn, Snoek, \& Rosenthal, 1964; Grobelna, 2015; Bettencourt \& Brown, 2003; Fisher, 2001; Tiyce et al., 2013; Arshad, Shahidan, Ibrahim Siam, \& Alshuaibi, 2020). Employees who are in direct contact with customers experience role ambiguity and role conflict in answering various demands from customers, managers, and other departments (O'Neill \& Davis, 2011; Hu \& Cheng, 2010; Kim, Ro, Hutchinson, \& Kwun, 2014; Walsh, 2011). Given these premises, role ambiguity, role conflict, and work overload are leading stress factors in the hospitality sector according to many researchers (Ross, 1995; Altintas \& 
Turanligil, 2018; Jogaratnam \& Buchanan, 2004; Cleveland et al., 2007; Hwang et al., 2014; Karatepe \& Ehsani, 2012; Karatepe \& Karatepe, 2010).

Role ambiguity and role conflict, which are among the main antecedents of work stress (Kahn et al., 1964; Grobelna, 2015; Bettencourt \& Brown, 2003; Fisher, 2001; Tiyce et al., 2013; CahayaSanthi \& Piartrini, 2020), occur mostly in large and complex organizational structures (Rizzo, House, \& Lirtzman, 1970). A dynamic organizational environment and a changing employment and technological structure are also situational factors (Kahn et al., 1964). Role ambiguity and role conflict are common experiences in hospitality workplaces, due to the largely intangible nature of the service, concurrent consumption and production, and the key role of employees in producing the hospitality product (Tiyce et al., 2013). According to O'Neill and Davis's (2011) study, hotel employees experience work stress on $40-62 \%$ of workdays and the most common stress factors are inter-personal conflicts and role overload.

Hundreds of studies on the personal and organizational consequences of role conflict and role ambiguity indicate the high degree of attention of organizational studies on the subject. Past research points to many direct and indirect negative outcomes. The meta-analysis on 43 studies conducted by Fisher and Gitelson (1983) shows that role ambiguity and role conflict have negative effects on commitment, engagement, job satisfaction, and employee turnover. Similarly, Jackson and Schuler (1985) conducted a meta-analysis on approximately 200 studies and found that role ambiguity and role conflict cause low job satisfaction, stress, low commitment, intention to leave, absenteeism, and low job performance. According to Rizzo et al. (1970), employees experience stress, anxiety, low self-esteem, low job satisfaction, low productivity, and hostile feelings toward their organizations.

As stated above there are many studies on the effects of role ambiguity and role conflict on job performance and job satisfaction. Although organizational behavior researchers have studied role stress factors in detail, there seems to be a very limited number of studies which focus on the context of the tourism and hospitality sector. However, accommodation businesses in particular, where customers with a wide range of needs and expectations receive service $24 / 7$, and employees have to work in a dynamic and unstable environment (Grobelna, 2015), constitute an ideal setting for problems stemming from role ambiguity and role conflict. This study aims to understand the mediating effect of job satisfaction on the relationship between role ambiguity, role conflict, and job performance in accommodation businesses.

This study has the potential to contribute to the organizational behavior and tourism and hospitality literature in certain aspects. First, although it is widely accepted that the hotel industry is stressful for employees, it hasn't attracted enough attention from work stress researchers (Jones, Chonko, Rangarajan, \& Roberts, 2007; Cho, Johanson, \& Guchait, 2009;
Kim et al., 2009). So, examining role stress factors in the context of the hotel industry is believed to advance the literature. Moreover, even though it is commonly accepted that role ambiguity and role conflict cause low job performance, the mediating role of job satisfaction has not yet been empirically tested in the hospitality sector to the best knowledge of the authors of this paper. This research proposes that job satisfaction may be a key factor in explaining how role conflict and role ambiguity influence job performance.

The paper continues as follows: First, the theoretical framework of the study will be presented. After giving information about role ambiguity and role conflict, job satisfaction and job performance, the hypotheses will follow. The hypotheses will be developed based on theory and the results of past studies. Then the research model will be presented. Following the research model, the results of the confirmatory factor analysis (CFA) and the structural equation modeling (SEM) will be introduced. Finally, theoretical and managerial implications of the findings, contributions, limitations, and future research directions will be discussed.

\section{Theoretical Framework}

\subsection{Role Ambiguity and Role Conflict}

Since the late 1950s and early 1960s, role ambiguity and role conflict along with other role theory constructs have gained serious attention in organizational behavior literature (Merton, 1957; Kahn et al., 1964). The theoretical base of role conflict and role ambiguity in organizations was provided by Kahn et al. (1964). Their role episode model explains the role phenomenon as a dynamic and continuous interaction between role senders (role set) and the role owner (focal person). This interaction takes place within a context influenced by organizational and individualistic factors such as size of the organization or motives and values of the role owner. According to the model, the role set demands the requirements of a particular role. The role owner perceives and processes the expectations and decides the right set of behaviors. Then the focal person performs the role, receives feedback and reevaluates her/his behaviors. It is important to note that the focal person always performs a perceived role. The perceived role behaviors may not satisfy the role set, and role senders' expectations may take the form of role pressures in the focal person's mind. The focal person might feel stressed about what role behaviors to perform and how to perform them as a result of role ambiguity and/or role conflict.

Role ambiguity occurs when the employee "does not feel she/he has the necessary information to perform her/his role adequately, when she/he is uncertain about what the members of her/his role set expect of her/him" (Walker, Churchill Jr, \& Ford, 1975). This uncertainty may be regarding the task or the social environment. When an employee cannot be sure of the job requirements or ways to succeed, she/he may experience task ambiguity. Similarly, an employee suffers from socioemotional ambiguity when she/he cannot predict the possible outcomes of her/his informal behaviors (King \& King, 1990). 
Formal job definitions are usually highly effective in clarifying roles. However, a role is different than a job description. There are also informal and humanistic factors that form a role. Even if the job descriptions are crystal clear, people's expectations about a position may vary significantly (Rogers \& Molnar, 1976). Role ambiguity can be a result of organizational or individual factors. Organizational factors include indefinite identifications of the role and communication errors in delivering the role requirements to the role owner. A complicated and frequently changing organizational structure, environmental changes, and insufficient organizational communication may trigger role ambiguity (Kahn et al., 1964). Individual factors are the factors that stem from the role owner. If the role owner doesn't perceive the requirements of the role, she/he cannot play it adequately. There must be a consensus between the role set and the role owner (Bible \& McComas, 1963; Greene \& Organ, 1973).

Gullahorn (1956) defines role conflict as a situation which occurs as a result of incompatible role demands. According to Kahn et al.'s (1964) role theory, role conflict includes two or more role pressures from various sources. According to the classical organization theory, role conflict has no place in a wellstructured organization with a solid chain of command (Rizzo et al., 1970). A position in the organization must come with a single role definition (Katz \& Kahn, 1978). On the other hand, modern organizations have to change structurally according to environmental changes. Moreover, role conflict may arise not just out of organizational issues but also out of human relations (Nicholson \& Goh, 1983). Role conflict in organizations is studied under various categories such as intra-sender conflict, inter-sender conflict, inter-role conflict and person-role conflict (Katz \& Kahn, 1978). Intra-sender conflict occurs when a given member of a role set holds incompatible expectations (Griffin \& Moorhead, 1989). Inter-sender conflict is the result of incompatible expectations from different members of a role set. A typical example is having different instructions from different managers regarding a specific piece of work. Inter-role conflict occurs when the focal person carries two or more roles with incompatible expectations (Sieber, 1974). For example, a hotel employee may be required to play different roles at work such as guest relations specialist, manager, subordinate and colleague. Lastly, person-role conflict stems from incompatibility between the requirements of a role and the values, needs, talents, and personality of the role owner. A religious or ethical employee might feel very uncomfortable in fulfilling an unethical but essential instruction.

Role conflict and role ambiguity cause many individual and organizational deficiencies. Past research shows that low job satisfaction and low job performance are among the most important negative outcomes (Khuong \& Yen, 2016; Saha, Reddy, Mattingly, Moskal, Sirigiri, \& De Choudhury, 2019; CahayaSanthi \& Piartrini, 2020). Similar outcomes are observed in the hospitality sector. Karatepe and Uludag (2008) emphasize that hotel employees, especially those in frontline positions, experience severe role stress. And role conflict and role ambiguity are behind it (Karatepe \& Sokmen, 2006). According to the data collected from 1645 hotel employees, role ambiguity has a direct negative effect on service quality (Lin \& Ling, 2018). Furthermore, according to Grobelna, Sidorkiewicz, and Tokarz-Kocik (2016), both role conflict and role ambiguity are significant predictors of hotel employees' job satisfaction.

\subsection{Job Performance}

Job performance constitutes measurable activities of employees in fulfilling certain tasks and responsibilities (Viswesvaran \& Ones, 2000). It can briefly be identified as the task or role performance level of an employee. The requirements of a certain task or a certain role are decided by the management (Campbell, 1990). So, job performance is an indicator of how well employees fulfill the job requirements for a certain position (Boshoff \& Arnolds, 1995). Job performance is considered a multi-dimensional phenomenon in the literature (Befort \& Hattrup, 2003; Viswesvaran \& Ones, 2000). The most cited study on job performance (Borman \& Motowidlo, 1993) presents two main dimensions - task performance and contextual performance. Task performance represents employee effort to accomplish expected tasks and responsibilities (Borman \& Motowidlo, 1993; Robbins \& Judge, 2017). Being highly related to the role requirements of the job, task performance constitutes the necessary behaviors which are identified in the job definition (Conway, 1999). Contextual performance, on the other hand, has no direct relation to tasks and responsibilities. It can be identified as the sum of behaviors which support the social and psychological context of an organization (Borman, 2004; Borman \& Motowidlo, 1997). In this study, job performance is considered and analyzed as task performance.

Role clarity is an important indicator of task performance. Past studies show that task performance is negatively influenced by role ambiguity and role conflict. The meta-analysis by Abramis (1994) in which 88 studies were examined clearly indicates that role ambiguity has a negative effect on job performance and job satisfaction. Moreover, job satisfaction has a significant positive effect on job performance for hotel employees (Sari, Bendesa, \& Antara, 2019).

\subsection{Job Satisfaction}

Job satisfaction is an indicator of employees' contentedness regarding their jobs (Hackman \& Oldham, 1975). Job satisfaction is expected to arise when job-related expectations, values and standards match with the job itself (Gordon, 1999). As expected, job satisfaction has many positive outputs for both organizations and employees. There are many studies in the literature which show that employees with a high level of job satisfaction tend to have higher commitment to their organization and are willing to be more productive and loyal. Job satisfaction is essential to the hotel industry, which has a service- and people-oriented nature. Satisfied employees have attitudes and behaviors that meet customer expectations. This increases service quality which leads to customer satisfaction 
and loyalty (Rust, Stewart, Miller, \& Pielack, 1996; Kim, Leong \& Lee., 2005; Karatepe \& Sokmen, 2006).

Past studies show that job satisfaction is essential to customer satisfaction and therefore to financial performance and welfare in hotels (Borralha, de Jesus, Pinto, \& Viseu, 2016). However it may be the most fragile component of success. As Kim et al. (2009, p. 612) state, job satisfaction is accepted as "one of the most subsequent job outcomes affected by role stress." And the context of tourism and hospitality is no exception. Role conflict and role ambiguity are negatively related to job satisfaction in the field of hospitality and tourism (Jung \& Yoon, 2015; Lee \& Hwang, 2016; Madera, Dawson, \& Guchait, 2016; Kong, Jiang, Chan, \& Zhou, 2018; Park, Ahn, Han, Back, \& An, 2020).

\section{Hypotheses}

Working in a hotel can be a substantial source of stress because of the dynamic work environment and the high demand fluctuation (Faulkner \& Patiar, 1997). Role ambiguity, role conflict, and excessive workload are accepted as the main stress factors in accommodation businesses (Ross, 1995; Altintas \& Turanligil, 2018; Jogaratnam \& Buchanan, 2004; Cleveland et al., 2007; Hwang et al., 2014; Karatepe \& Ehsani, 2012; Karatepe \& Karatepe, 2010). Hu and Cheng (2010), in their study on hotel managers in Taiwan, state that workload and job characteristics are strong antecedents of work stress. According to O'Neill and Davis (2011), hotel managers experience more stress in comparison to employees who have no managerial responsibilities. According to Zohar's (1994) study on hotel employees in Canada, role ambiguity and excessive work overload are strong stress factors, whereas role conflict doesn't seem to have a significant effect. On the other hand, Hwang et al. (2014), Kim et al. (2009), and Young and Corsun (2009) state that role conflict is an important stress factor. Cleveland et al. (2007) point to long, irregular, and unpredictable work hours as the most common work stress factors for hotel managers. According to their study, stress factors vary depending on department. Managers in the food and beverage department have an irregular schedule that includes holidays and weekends, whereas managers in human resources and accounting departments have a standard and planned schedule.

Role ambiguity and role conflict, which are the main role stress factors, have many direct or indirect negative consequences. According to Fisher and Gitelson's (1983) and Jackson and Schuler's (1985) meta-analyses, role ambiguity and role conflict negatively affect organizational commitment, job satisfaction, job performance and employee turnover. They also cause high levels of stress and absenteeism. The literature reveals that one major consequence of role ambiguity and role conflict is job dissatisfaction. Numerous studies prove that role ambiguity and role conflict have a direct negative effect on job satisfaction (House \& Rizzo, 1972; Keller, 1975; Blalack \& Davis, 1975; Bedeian \& Armenakis, 1981; Brief \& Aldag, 1976; Miles \& Perreault, 1976; Acker, 2004; Faucett, Corwyn \& Poling., 2013).
Furthermore, this negative effect appears indirectly through the medium of stress (Bedeian \& Armenakis, 1981; Goolsby, 1992), burnout (Reetz, 1988), and success-orientation (Johnson \& Stinson, 1975). Role ambiguity and role conflict are important antecedents of job dissatisfaction for tourism and hospitality employees as well (Kim et al., 2009; Yang, 2010; Ross \& Boles, 1994; Kong et al., 2018; Hight \& Park, 2019). The above findings are also in line with the fact that role theory (Kahn et al., 1964) hypothesizes that role conflict and role ambiguity are negatively related to job satisfaction and performance (Schuler, 1975).Thus, the following hypotheses are proposed:

H1: Role conflict has a negative effect on job satisfaction for hotel employees.

H2: Role ambiguity has a negative effect on job satisfaction for hotel employees.

Job performance is essential to an organization's success and employees are the most important asset for tourism and service organizations (Kuşluvan, Kuşluvan, İlhan \& Buyruk, 2010; Wu \& Liang, 2009; Law et al., 1995; Barsky, Thoresen, Warren \& Kaplan, 2004; Choi \& Chu, 2001; Shamim, Cang, \& Yu, 2017). Employees who can fulfill customer expectations provide a competitive advantage for their organizations (Hu, Horng \& Sun, 2009). Still, human resources has a certain disadvantage, which is that employees are social and emotional beings who are open to the negative effects of the work environment (MacKinlay, 2003). Work stress has a negative effect on employees' job satisfaction and job performance (Chuang \& Lei, 2011; O'Neill \& Davis, 2011; Bemana, Moradi, Ghasemi, Taghavi \& Ghayoor, 2013; Ross, 1997; Hsieh \& Yen, 2005; Tubre \& Collins, 2000; Barsky et al., 2004). Role ambiguity and role conflict are among the main work stress factors (Kahn et al., 1964; Grobelna, 2015; Bettencourt \& Brown, 2003; Fisher, 2001; Tiyce et al., 2013).

Low job performance seems to be a main consequence of role ambiguity and role conflict (Bible \& McComas, 1963; House \& Rizzo, 1972; Dubinsky \& Mattson, 1979; Miles \& Perreault, 1976; Fried, Ben-David, Tiegs, Avital \& Yeverechyahu, 1998; Zhou, Martinez, Ferreira, \& Rodrigues, 2016; Amilin, 2017). This causality is also observed in the tourism and hospitality industry. In his study on hotel employees, Akgunduz (2015) found that role ambiguity and role conflict are negatively associated with job performance. Likewise, Karatepe and Uludag (2008) found a negative effect of job ambiguity on performance in their study on hotel employees in Northern Cyprus. Gilboa, Shirom, Fried \& Cooper (2008) state in their meta-analysis that work stress is a strong antecedent of low job performance for hotel employees, especially for those in managerial positions. June and Mahmood's (2020) study also revealed that role ambiguity is a critical antecedent of job performance for service employees. So, in the light of role theory and the findings stated above:

H3: Role conflict has a negative effect on job performance for hotel employees. 
H4: Role ambiguity has a negative effect on job performance for hotel employees.

Job satisfaction is an important predictor of job performance (Judge, Thoresen, Bono \& Patton, 2001; Indarti, Fernandes, \& Hakim, 2017). In fact, for decades, researchers have been so attracted to the relationship between job satisfaction and job performance that the search for ithas been referred to as the "Holy Grail" of the organizational behavior discipline (Weiss \& Cropanzano, 1996). Even though past studies reveal a moderate-weak causality, researchers agree on a "commonsense" that satisfied employees perform better (Fisher, 2003). This common sense also has empirical evidence in the context of the service sector. High satisfaction improves productivity, whereas low satisfaction lowers performance (Yoon \& Suh, 2003; Siengthai \& Pila-Ngarm, 2016). Moreover, a systematic review of the literature shows that job satisfaction is crucial to the job performance of hotel employees, and job satisfaction increases in the absence of role stress factors (Borralha et al., 2016). The mediating effect of job satisfaction on the relationship between role stress and job performance in various organizations (Fried et al., 2008) is to be tested in the hospitality sector. Therefore, the following hypotheses are proposed:

H5: Job satisfaction has a positive effect on job performance for hotel employees.

H6: Job satisfaction has a mediating effect in the relationship between role ambiguity and role conflict and job performance.

\section{Research Model}

The explanatory research approach was adopted. Explanatory research aims to understand the causal effects between variables. Accordingly, this study focuses on the mediating effect of job satisfaction on the effect of role ambiguity and role conflict on job performance. In the research model, role ambiguity and role conflict are independent variables, whereas job performance and job satisfaction are dependent and mediating variables, respectively. Structural equation modeling (SEM) was utilized in order to test the multiple causalities in the model.

\subsection{Sample}

The population of the research consists of employees who work in five-, four- and three-star accommodation businesses in Alanya. Alanya is an important and popular tourism destination in the southern region of Turkey, and $11.60 \%$ of the country's total five-star accommodation businesses are located there. The situation is similar for other types of hospitality businesses as well (four-star hotels, apart hotels, etc.) (Yılmaz, Üngüren \& Kaçmaz, 2019). After time and cost limitations were considered, purposive sampling, which is a nonrandom sampling method, was utilized for the research. The data was collected via questionnaire forms. Approximately 900 forms were distributed to 28 hotels and 623 of those forms were collected. Forty-eight returned forms were left blank by the participants, so they were not included in the analysis. A further 41 forms were not included in the analysis because they were detected as outliers when boxplot and mahalanobis analyses were conducted. A total of 534 questionnaire forms were included in the analysis. Therefore, the minimum sample size requirement for SEM is adequately fulfilled statistically (Anderson \& Gerbing, 1988).

\subsection{Measurement Tools}

To measure employee perceptions of role ambiguity and role conflict, the role ambiguity and role conflict scale developed by Rizzo et al. (1970) was used. The reliability of the scale was proved by Schuler, Aldag \& Brief (1977) and House, Schuler \& Levanoni (1983). Rizzo et al. (1970) conducted the questionnaire on 1573 employees and the internal consistency coefficients were 0.87 and 0.82 for role ambiguity and role conflict, respectively. As the scale has been widely utilized in the literature, it has been frequently tested. In Jackson and Schuler's (1985) meta-analysis covering 200 studies on role ambiguity and role conflict, the reliability coefficient of the scale is 0.76 at minimum. The mediating variable, job satisfaction, was measured via the job satisfaction subscale of the Michigan Organizational Assessment Questionnaire. The scale has high internal consistency according to past research (Spector, 1997). Bowling and Hammond (2008) have also presented its construct validity. To measure job performance, which is the dependent variable of the research, three items from Ramos-Villagrasa, Barrada, Fernández-del-Río \& Koopmans 2019) study were adapted. Even thoughit can be a subject of debate, Karatepe et al. (2006) state that the use of a self-report measure for performance does not lead to inflated results. The questionnaire items were on a five-point Likert-type scale, ranging from 1 (strongly disagree) to 5 (strongly agree). A pilot study was conducted on 30 employees before the data collection process in order to ensure an accurate and healthy measurement. As it was determined through the preliminary study that there was no problem, the items remained unchanged.

\subsection{Data analysis}

Before the research model was tested, extreme outliers were identified with boxplot and mahalanobis analysis. To determine the normal distribution, skewness and kurtosis values were examined. The demographic data of the participants was analyzed via frequency and percentage analyses. The research model was tested in two phases as proposed by Anderson and Gerbing (1988). In phase one, reliability and validity results of the measurement were determined via confirmatory factor analysis (CFA). Besides the goodness of fit indexes, convergent validity and discriminant validity values were also calculated in order to test the construct validity and reliability of the scales. In phase two, the hypotheses of the study were tested via structural equation modeling (SEM). The mediating effect of job satisfaction on the relationship between role ambiguity and role conflict and job performance was tested the by B-K method (Baron \& Kenny, 1986). 


\section{Results}

\subsection{Demographic findings}

Participants' demographic characteristics are shown in Table 1. The study participants included 534 employees from various departments in 28 hotels. The percentages of male and female participants appeared to be very close. The overwhelming majority $(80.2 \%)$ of the respondents were between the ages of 18 and 37 . Most of the respondents were high school graduates
(46.3\%). Participants were from seven different hotel departments. The results indicated that most of the respondents were food and beverage (35\%) and front office (18.5\%) employees. As shown in Table 1, the majority (48.3\%) of the respondents worked in five-star hotels. Almost half of the participants $(45.9 \%)$ had been working in their current organization for less than a year, whereas only $9.4 \%$ had tenures of seven years or more.

Table 1. Demographic Breakdown of the Sample $(n=534)$

\begin{tabular}{|c|c|}
\hline & $\%$ \\
\hline \multicolumn{2}{|l|}{ Gender } \\
\hline Female & 44.8 \\
\hline Male & 55.2 \\
\hline \multicolumn{2}{|l|}{ Age } \\
\hline $18-27$ & 34.6 \\
\hline $28-37$ & 46.6 \\
\hline $38-47$ & 15.9 \\
\hline 48 and above & 2.8 \\
\hline \multicolumn{2}{|l|}{ Education } \\
\hline Primary School & 16.5 \\
\hline High School & 46.3 \\
\hline Two-year Degree & 20.8 \\
\hline Undergraduation & 16.5 \\
\hline \multicolumn{2}{|l|}{ Department } \\
\hline Front Office & 18.5 \\
\hline Housekeeping & 12.9 \\
\hline Accounting & 7.7 \\
\hline Human Resources & 6.9 \\
\hline Food and Beverage & 35.0 \\
\hline Kitchen & 12.5 \\
\hline Purchasing & 6.4 \\
\hline \multicolumn{2}{|l|}{ Hotel } \\
\hline Three-star & 21.9 \\
\hline Four-star & 29.8 \\
\hline Five-star & 48.3 \\
\hline \multicolumn{2}{|l|}{ Tenure } \\
\hline Less than 1 year & 45.9 \\
\hline $2-4$ years & 25.8 \\
\hline $5-6$ years & 18.9 \\
\hline 7 years and above & 9.4 \\
\hline
\end{tabular}

\subsection{Measurement Model}

In our analysis of the measurement model, a two-step approach was utilized in the structural equation modeling analysis based on Anderson and Gerbing (1988). In step one, the reliability and validity of the measurement model were tested via confirmatory factor analysis. In step two, the hypotheses were tested via structural equation modeling. The confirmatory factor analysis results are shown in Table 2. The measurement model reveals that goodness-of-fit statistic values are very satisfactory $\quad(\chi 2=213.007, \quad d f=112, \quad \chi 2 / d f=1,902 ; \quad p=.000$;
RMSEA $=.041 ; \quad \mathrm{AGFI}=.940, \mathrm{GFI}=.956, \quad \mathrm{CFI}=.994, \quad \mathrm{FI}=.994$, $\mathrm{NFI}=.988, \mathrm{RFI}=.985$ ). According to the CFA results in Table 2 , the standardized factor load values for each item are above 0.70 . All items in scales have a high $t$ value and factorized in a statistically significant way $(p<0.05)$. Skewness and kurtosis values were calculated to test the normality distribution. Skewness and kurtosis values of the items took a value between +1.5 and -1.5 , which indicates that the data meets the multivariate normality assumption (Tabachnick \& Fidell, 2007).

Table 2 - Results of the Measurement Model

\begin{tabular}{|c|c|c|c|c|c|c|c|}
\hline Constructs & Items & Mean & Standardized Loadings & t-Value & Skewness & Kurtosis & Cronbach's alpha \\
\hline \multirow{6}{*}{$\begin{array}{l}\text { Role } \\
\text { Ambiguity }\end{array}$} & Ambiguity 1 & 2.90 & .921 & Fixed & -0.06 & -0.90 & \multirow{6}{*}{.911} \\
\hline & Ambiguity 2 & 2.97 & .909 & $77.057^{* *}$ & 0.00 & -0.91 & \\
\hline & Ambiguity $3(-)$ & 2.93 & .858 & $67.444^{* *}$ & -0.04 & -0.87 & \\
\hline & Ambiguity 4 & 2.92 & .833 & $65.064^{* *}$ & -0.03 & -0.87 & \\
\hline & Ambiguity 5 & 2.95 & .826 & $60.322 * *$ & -0.02 & -0.84 & \\
\hline & Ambiguity 6 (-) & 2.96 & .808 & $59.583^{* *}$ & 0.01 & -0.81 & \\
\hline & Conflict 1 & 2.79 & .948 & Fixed & 0.21 & -0.85 & \\
\hline & Conflict 2 & 2.81 & .920 & $72.341 * *$ & 0.19 & -0.83 & \\
\hline
\end{tabular}




\begin{tabular}{|c|c|c|c|c|c|c|c|}
\hline Constructs & Items & Mean & Standardized Loadings & t-Value & Skewness & Kurtosis & Cronbach's alpha \\
\hline \multirow{3}{*}{ Role Conflict } & Conflict $3(-)$ & 2.81 & .848 & $69.933 * *$ & 0.21 & -0.88 & \multirow[t]{3}{*}{.923} \\
\hline & Conflict 4 & 2.84 & .820 & $67.454^{* *}$ & 0.11 & -0.85 & \\
\hline & Conflict $5(-)$ & 2.80 & .769 & $65.429 * *$ & 0.21 & -0.78 & \\
\hline \multirow{3}{*}{$\begin{array}{l}\text { Job } \\
\text { Satisfaction }\end{array}$} & Satisfaction 1 & 3.08 & .918 & Fixed & -0.20 & -0.80 & \multirow{3}{*}{.916} \\
\hline & Satisfaction $2(-)$ & 3.10 & .902 & $51.255^{* *}$ & -0.11 & -0.82 & \\
\hline & Satisfaction 3 & 3.08 & .878 & $46.100^{* *}$ & -0.27 & -0.84 & \\
\hline \multirow{3}{*}{$\begin{array}{l}\text { Job } \\
\text { Performance }\end{array}$} & Performance 1 & 3.74 & .965 & Fixed & 0.02 & -1.17 & \multirow{3}{*}{.918} \\
\hline & Performance 2 & 3.76 & .910 & 87.852 & 0.01 & -1.19 & \\
\hline & Performance 3 & 3.73 & .878 & 65.293 & 0.05 & -1.15 & \\
\hline
\end{tabular}

In the next step of the measurement model, convergent validity, discriminant validity, and construct reliability were examined for construct validity. As shown in Table 3, all composite reliability (CR) values of the constructs exceed the recommended threshold of 0.70 . Also, it can be seen that average variance extracted (AVE) values for all variables are above 0.50 and CR values are higher than AVE values (Table 3). These results show that all variables in the research model have convergent validity (Fornell \& Larcker, 1981). MSV (maximum shared variance), ASV (average shared variance) and cross loading values were calculated in order to test discriminant validity. Scales have discriminant validity when MSV and ASV values are lower than AVE values, and when the square root values of AVE are higher than the correlation values of corresponding variables, according to Fornell and Larcker (1981). Accordingly, as seen in Table 3, MSV and ASV values of all the variables in the model are lower than AVE values, and the squares of all correlation values are lower than AVE values. To test the reliabilities of the scales, Cronbach's Alpha values were calculated. Cronbach's Alpha values appear to be between .911 and .923 (Table 2). This also indicates that the scales are statistically reliable (Hair et al., 2010). In general, it was determined that the research model is reliable and has convergent and discriminant validities.

Table 3 - Convergent and Discriminant Validity of Model

\begin{tabular}{|l|c|c|c|c|c|c|c|c|}
\hline & $\mathbf{1}$ & $\mathbf{2}$ & $\mathbf{3}$ & $\mathbf{4}$ & $\mathbf{A V E}$ & $\mathbf{C R}$ & MSV & ASV \\
\hline 1. Job Satisfaction & 1 & & & & .809 & .927 & .281 & .219 \\
\hline 2. Job Performance & 0.53 & 1 & & & .843 & .942 & .281 & .172 \\
\hline 3. Role Ambiguity & -0.422 & -0.338 & 1 & & .740 & .945 & .339 & .210 \\
\hline 4. Role Conflict & -0.446 & -0.347 & 0.582 & 1 & .746 & .936 & .339 & .219 \\
\hline
\end{tabular}

\subsection{Structural model}

After the research model was validated, the hypotheses were tested via SEM. In this step, the mediating effect of job satisfaction on the relationship between role ambiguity and role conflict and job performance was tested. Baron and Kenny
(1986) state three conditions for a mediation model. These conditions are (1) the independent variable must have a significant effect on the dependent variable; (2) the independent variable must have a significant effect on the mediating variable(s), and (3) the mediating variable must have a significant effect on the dependent variable (Figure 1).

Figure 1 - The testing model of the study

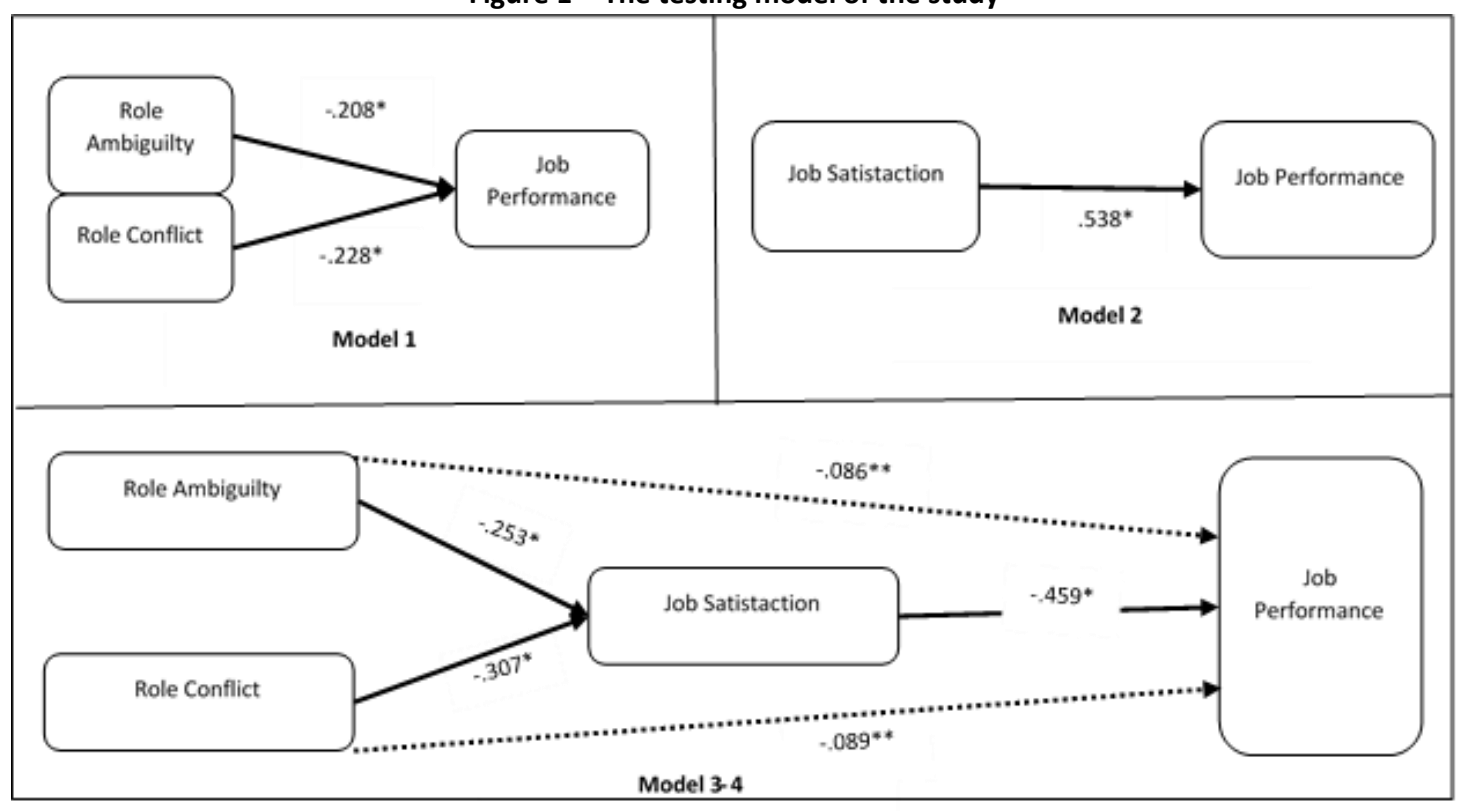


Accordingly, a three-step SEM analysis was conducted (Figure 1). The goodness-of-fit statistic values of SEM results in Model 1 are seen to be satisfactory $(\chi 2=176.307, d f=74, \chi 2 / d f=2.38$; $\mathrm{p}=.000 ; \mathrm{RMSEA}=.051 ; \mathrm{AGFI}=.938, \mathrm{GFI}=.956, \mathrm{CFI}=.993, \mathrm{IFI}=.993$, $\mathrm{NFI}=.988, \mathrm{RFI}=.986)$. According to the results of Model 1 in Figure 1 , role conflict $(\beta=-.228, p<.001)$ and role ambiguity $(\beta=-$ $.208, p<.001)$ have a negative and statistically significant effect on job performance. So, the first condition (Baron \& Kenny, 1986 ) is fulfilled. Model 2 's goodness-of-fit statistic values are seen to be satisfactory also $(\chi 2=30.582, \mathrm{df}=8, \chi 2 / \mathrm{df}=3.82$; $\mathrm{p}=.000 ; \mathrm{RMSEA}=.052 ; \mathrm{AGFI}=.952, \mathrm{GFI}=.982, \mathrm{CFI}=.995, \mathrm{IFI}=.995$, $\mathrm{NFI}=.994, \mathrm{RFI}=.988$ ). The SEM results of Model 2 show that job satisfaction, which is the mediating variable, has a positive and significant effect on job performance $(\beta=.538, p<.001)$, which is the dependent variable. So, the second condition for a mediating model is also fulfilled. Model 3's goodness-of-fit statistic values are also satisfactory $(\chi 2=176.134, d f=74$, $\chi 2 / d f=2.38 ; \quad \mathrm{p}=.000 ; \quad \mathrm{RMSEA}=.051 ; \quad \mathrm{AGFI}=.936, \quad \mathrm{GFI}=.955$, $\mathrm{CFI}=.933, \mathrm{IFI}=.993, \mathrm{NFI}=.988, \mathrm{RFI}=.985)$. According to the SEM results of Model 3, the independent variables of the model, which are role conflict $(\beta=-.307, p<.001)$ and role ambiguity $(\beta=-$ $.253, p<.001)$, have a negative and significant effect on job satisfaction, which is the mediating variable. The results of the analyses for all three models seem to fulfill the conditions determined by Baron and Kenny (1986).

Model 4 which is shown in Table 4 shows the results of the mediating effect of job satisfaction on the effect of role conflict and role ambiguity on job performance. The statistical values of Model 4 indicate the integrity of the model $(\chi 2=2013.007$ $\mathrm{df}=112, \chi 2 / \mathrm{df}=1.90 ; \mathrm{p}=.000 ; \mathrm{RMSEA}=.041 ; \mathrm{AGFI}=.940, \mathrm{GFI}=.956$, $\mathrm{CFI}=.994, \mathrm{IFI}=.994, \mathrm{NFI}=.988, \mathrm{RFI}=.985)$. The results in Table 4 show that when the mediating variable, which is job satisfaction, is included in the model, the effect of role conflict $(\beta=-.089, p>.005)$ and role ambiguity $(\beta=-.086, p>.005)$ on job performance seems to diminish. In other words, the SEM results of Model 4 prove that job satisfaction has a significant mediating effect on the relationship between role conflict, role ambiguity, and job performance.

Table 4 - The Results Regarding Structural Equation Modeling

\begin{tabular}{|l|l|l|l|l|l|l|}
\hline & & & & $\boldsymbol{\beta}$ & $\mathbf{t}$ & $\mathbf{p}$ \\
\hline \multirow{3}{*}{ Model 1 } & Role Conflict & $\rightarrow$ & Job Performance & -.228 & -4.542 & .000 \\
\cline { 2 - 7 } & Role Ambiguity & $\rightarrow$ & Job Performance & -.208 & -4.147 & .000 \\
\hline Model 2 & Job Satisfaction & $\rightarrow$ & Job Performance & .538 & 14.007 & .000 \\
\hline \multirow{4}{*}{ Model 3 } & Role Conflict & $\rightarrow$ & Job Satisfaction & -.307 & -6.391 & .000 \\
\cline { 2 - 7 } & Role Ambiguity & $\rightarrow$ & Job Satisfaction & -.253 & -5.262 & .000 \\
\hline \multirow{4}{*}{ Model 4 } & Role Conflict & $\rightarrow$ & Job Performance & -.086 & -1.844 & .069 \\
\cline { 2 - 7 } & Role Ambiguity & $\rightarrow$ & Job Performance & -.089 & -1.817 & .048 \\
\cline { 2 - 7 } & Role Conflict & $\rightarrow$ & Job Satisfaction & -.307 & -6.390 & .000 \\
\cline { 2 - 7 } & Role Ambiguity & $\rightarrow$ & Job Satisfaction & -.253 & -5.280 & .000 \\
\cline { 2 - 7 } & Job Satisfaction & $\rightarrow$ & Job Performance & .459 & 10.522 & .000 \\
\hline
\end{tabular}

\section{Discussion and Conclusion}

This study examined the effect of role stress factors, which are role conflict and role ambiguity, on job performance, as mediated by job satisfaction in the context of tourism and hospitality. Empirical results supported the proposed model of the study. More specifically, the results showed that both role conflict and role ambiguity have direct negative influences on job performance and job satisfaction for hotel employees. Moreover, it was also proved that job satisfaction mediates the effect of role conflict and role ambiguity on job performance. The theoretical and practical implications of these findings are discussed below.

The findings make certain contributions to the existing literature. Most importantly, gathering empirical findings regarding the outcomes of role stress factors in the context of accommodation businesses is important to advance the existing tourism and hospitality literature. This study answered a call from past studies that hotels constitute a stressful work environment and must be examined more thoroughly (Kim et al., 2009). Characterized by uncertainties, changing customer needs, and conflicting demands of customers and hotel management, hotels are indeed favorable environments for role conflict and role ambiguity (Faulkner \& Patiar, 1997). According to Sönmez, Apostolopoulos, Lemkeb, and Hsieh (2020), hospitality employees have experienced a serious increase in job stress in the last 15-20 years compared to other sectors. And The World Health Organization declared workrelated stress as one of the biggest challenges of the 21st century (Houtman, Jettinghoff, \& Cedillo 2007). Role conflict and role ambiguity are major sources of job stress (Tameirão \& Nunes, 2019).

The empirical findings of this study support the findings of past studies. Employee job performance, as a major indicator of organizational performance, is studied frequently in management literature. Service quality, which is the leading success factor in the tourism and hospitality sector (AlAbabneh, 2018), is highly correlated with job performance (Machado et al., 2019). High performing employees are crucial for competitive advantage (Li, Sanders, \& Frenkel; Üngüren, 2019; Wu \& Ko, 2013; Yun, Takeuchi, \& Liu, 2007). Accordingly, it is critically important to understand the factors that affect employee job performance in accommodation businesses (Karatepe \& Sokmen, 2006). Successful companies allocate 
resources to search for ways of increasing employee job performance (George \& Weimerskirch, 1994). Past studies found that job satisfaction has an important effect on employee job performance (Bayfield \& Crockett, 1955; Judge et al., 2001; Sheridan \& Slocum, 1975; Riketta, 2008; Borralha et al., 2016). High levels of job satisfaction increase employee productivity, whereas job dissatisfaction has significant negative effects (Yoon \& Suh, 2003; Jankingthong \& Rurkkhum, 2012). Job satisfaction seems to be the most frequently studied phenomenon in the context of tourism and hospitality (Borralha et al., 2016). This study also shows that job satisfaction has a positive effect of employee job performance.

The existing literature also shows that role conflict and role ambiguity cause many negative organizational and individual outcomes, including low job satisfaction and low job performance (Rizzo et al., 1970; Ross \& Boles, 1994). In the hospitality sector, even if job descriptions are solidly determined, various and changing demands from customers and hotel management may cause role conflict and role ambiguity among employees (Kim et al., 2009). Past research conducted in accommodation businesses shows that role conflict and role ambiguity have negative effects on job satisfaction and job performance (Karatepe \& Uludağ, 2008; Grobelna, 2015). Consistent with the findings of prior empirical research, the proposed model of this study is supported by data. So, according to the results, role conflict and role ambiguity have a negative effect on both job satisfaction and job performance. Also, job satisfaction has a mediating effect on the relationship between role ambiguity, role conflict and job performance. In other words, role conflict and role ambiguity cause job dissatisfaction among hotel employees, which subsequently leads to low job performance. The results are believed to be important both for researchers and practitioners in the hospitality sector.

The effect of employee performance on an organization's success cannot be denied. A company achieves its goals through the work of its employees (Campbell, 1990; Rotundo \& Sockett, 2002). Employees play an even greater role in the hospitality and service sectors, where customer satisfaction and loyalty are created through direct contact (Choi \& Chu, 2001). Tourism management literature points to a linear relationship between employee job performance and service quality for accommodation businesses (Wu \& Ko, 2013; Mei, Dean, \& White, 1999; Clemes, Wu, Hu, \& Gan, 2009). However, job stress seems to be a problem which must be solved effectively by managers as it affects job performance negatively (Ross, 1995). It is known that when proper coping strategies are developed and implemented, job stress levels can be reduced, if not removed altogether (O'Neill \& Davis, 2011).

The results seem to have clear advice for managers and practitioners in hospitality sector: To increase employee performance in a hotel, management must be aware of employees' feelings and desires at their workplace. Employees don't fulfill their tasks adequately when they have negative feelings toward their company. One of the reasons an employee has negative feelings is role stress, which includes role conflict and role ambiguity (Schuler, 1985). So, specifically, role stress factors must be addressed seriously. Evaluation and determination of factors that cause role conflict and role ambiguity could be the first step. According to Karatepe (2010), close supervision decreases the effect of role conflict and role ambiguity on job satisfaction. Lin and Ling (2018) also state that psychological empowerment may diminish the negative effect of role ambiguity on service quality. Similarly, Kaya (2010) also addresses the role of supervisors in the hospitality sector: A healthy relationship and harmony between supervisors and employees improve job satisfaction and performance.

Managers may improve their employees' job performance (and job satisfaction) by ensuring that employees understand what is expected of them and how their effort makes a difference. When the right person is employed in the right position under favorable conditions, she/he can turn her/his potential into superior performance. In order to choose the right person for the right job, the company must first clarify the job requirements and job responsibilities (Üngüren, 2019). The findings by Rod, Carruthers \& Ashill (2006) show that clarified roles and responsibilities reduce role ambiguity for frontline employees. Moreover, managers must also ensure that employees don't receive conflicting orders from different sources and don't have to deal with an excessive workload. Removing sources of role stress and dissatisfaction from the work environment will keep employees productive and satisfied (Kumar, Dass \& Topaloglu, 2014) and enable them to contribute significantly to organizational success (Cho, Choi, \& Lee, 2014; Chuang \& Lei, 2011).

According to the findings of the study, job satisfaction seems to be a key component that can diminish the negative effects of role conflict and role ambiguity on job performance. Past research also suggests that low job satisfaction harms performance and reduces customer satisfaction (Yee, Yeung \& Cheng, 2008; Lambert \& Hogan, 2009). According to Kong et al. (2018), organizational support is crucial to increase job satisfaction. Furthermore, Acker (2004) states that the social support of managers also decreases employee role conflict. So, hotel managers must develop effective human resources practices to support their employees. Current studies point to the benefits of mindfulness training for employees, including the ability to manage difficult feelings, improved relationships (Warriner, Hunter \& Dymond, 2016), and increased levels of job satisfaction (Hülsheger, Alberts, Feinholdt \& Lang, 2013). Such training can be effective for job satisfaction and job performance.

\subsection{Limitations and implications for future research}

One important limitation of this study is that only a few factors that may influence job performance in hotels were controlled. Although a guiding causality was found, job performance of hotel employees surely must have many other affecting factors. 
So, the model can also be tested with additional behavioral and organizational factors specific to the hospitality sector. Another limitation might be the generalizability of the findings. Although the results are likely to be generalizable to other hotel properties in Turkey, it is possible that they do not generalize to other service firms or to those outside of Turkey. However, the fact that this study's findings are consistent with the findings of prior studies conducted in different contexts supports the generalizability of the current findings. Future studies are encouraged to collect data from different regions and different types of organizations in the tourism and hospitality sector. Furthermore, employment in the tourism and hospitality sector is being severely affected by the Covid-19 pandemic as it has hindered tourism activities all around the world (Yang, Zhang, $\&$ Chen, 2020). The pandemic also worsened the working conditions of tourism employees, which were stressful to begin with. Millions of employees had to go on unpaid leave or even lost their jobs because of the lockdown (Sönmez et al., 2020). In this context, it would be important to examine the effect of the Covid-19 pandemic on work stress and job performance for tourism and hospitality employees.

\section{References}

Acker, G. M. (2004). The effect of organizational conditions (role conflict, role ambiguitiy, opportunities for professional development, and social support) on job satisfaction and intention to leave among social workers in mental health care. Community Mental Health Journal, 40(1), 65-73.

Akgunduz, Y. (2015). The influence of self-esteem and role stress on job performance in hotel businesses. International Journal of Contemporary Hospitality Management, 27(6), 1082-1099.

Al-Ababneh, M.M., Masadeh, M.A., Al-Shakhsheer, F.J., \& Habiballahi, M.A. (2018) The impact of internal service quality on job satisfaction in the hotel industry. Research in Hospitality Management, 8(1), 55-62.

Altintas, V. \& Turanligil, F. (2018). Hotel employees' perceptions of stress factors. International Journal of Applied Engineering Research, 13(2), 1432-1441.

Amilin, A. (2017). The impact of role conflict and role ambiguity on accountants' performance: The moderating effect of emotional quotient. European Research Studies Journal, 20(2A), 237-249.

I Anderson, J. C. \& Gerbing, D. W. (1988). Structural equation modelling in practice: A review and recommended two-step approach. Psychological Bulletin, 103(3), 411-423.

Arshad, M. Z., Shahidan, A. N., Ibrahim Siam, I. M., \& Alshuaibi, A. S. (2020). Effect of role conflict and work overload on job stress: A case of banking sector employees. Talent Development \& Excellence, 12(3), 2686-2696.

Baron, R. M., \& Kenny, D. A. (1986). The moderator-mediator variable distinction in social psychological research: Conceptual, strategic, and statistical considerations. Journal of Personality and Social Psychology, 51(6), 1173.

Barsky, A., Thoresen, C. J., Warren, C. R., \& Kaplan, S. A. (2004). Modelling negative affectivity and job stress: $A$ contingency-based approach. Journal of Organizational Behavior, 25(8), 915-936.

Bayfield, A.H. \& Crockett, W.H. (1955). Employee attitude and employee performance. psychological bulletin, 5, 396-424.

Bedeian, A. G. \& Armenakis, A. A. (1981). A path-analytic study of the consequences of role conflict and ambiguity. Academy of Management Journal, 24(2), 417-424.
Befort, N., \& Hattrup, K. (2003). Valuing task and contextual performance: Experience, job roles, and ratings of the importance of job behaviors. Applied HRM Research, 8(1), 17-32.

Bemana, S., Moradi, H., Ghasemi, M., Taghavi, S. M., \& Ghayoor, H. (2013). The relationship among job stress and job satisfaction in municipality personnel in Iran. World Applied Sciences Journal, 22(2), 233-238.

Bettencourt, L.A. \& Brown, S.W. (2003). Role sterossor and cutomer oriented boundary spanning behaviors in service organizations. Journal of Academy of Marketing Sicience, 31(4), 394-408.

Bible, B. L., \& McComas, J. D. (1963). Role consensus and teacher effectiveness. Social Forces, 42(2), 225-233.

Blalack, R. O. \& Davis, H. J. (1975). Role ambiguity, job related tension and job satisfaction. Journal of Management, 1(1), 31-37.

Borman, W. C. (2004). The concept of organizational citizenship. Current Directions in Psychological Science, 13(6), 238-241.

Borman, W. C., \& Motowidlo, S. J. (1997). Task performance and contextual performance: The meaning for personnel selection research. Human Performance, 10(2), 99-109.

Borman, W. C., \& Motowidlo, S. M. (1993). Expanding the criterion domain to include elements of contextual performance. in N. Schmitt \& W. C. Borman (Eds.), Personnel Selection in Organizations (pp. 71-98), Wiley.

Borralha, S., Jesus, S. N., Pinto, P. \& Viseu, J. (2016). Job satisfactıon in hotel employees: A systematic review of the literature. Journal of Spatial and Organizational Dynamics, 4(1), 4-20.

Boshoff, C., \& Arnolds, C. (1995). Some antecedents of employee commitment and their influence on job performance: A multi foci study. South African Journal of Business Management, 26(4), 125-135.

Bowling, N.A. \& Hammond, G.D. (2008). A meta-analytic examination of the construct validity of the Michigan organizational assessment questionnaire job satisfaction subscale. Journal of Vocational Behavior, 73, 63-77.

Brief, A. P. \& Aldag, R. J. (1976). Correlates of role indices. Journal of Applied Psychology, 61(4), 468-472.

CahayaSanthi, N. P. M., \& Piartrini, P. S. (2020) The effect of role ambiguity on work related stress and employees' work satisfaction. American Journal of Humanities and Social Sciences Research, 4(6), 99107.

Campbell, J. P., McHenry, J. J., \& Wise, L. L. (1990). Modeling job performance in a population of jobs. Personnel psychology, 43(2), 313575.

Campbell, J.P. (1990). Modeling the performance prediction problem in industrial and organizational psychology, in Marvin D. Dunnette \& Leaetta M. Hough (Eds.), Handbook of Industrial and Organizational Psychology, Vol. 1, Palo Alto: Consulting Psychologists Press.

Chiang, F. F. T., Birtch, T. A. \& Kwan, H. K. (2010). The moderating roles of job control and work-life balance practices on employee stress in the hotel and catering industry. International Journal of Hospitality Management, 29, 25-32.

Cho, J-E., Choi, H.S.Ch., \& Lee, W.J. (2014). An empirical investigation of the relationship between role stressors, emotional exhaustion and turnover intention in the airline industry. Asia Pacific Journal of Tourism Research, 19(9), 1023-1043.

Cho, S., Johanson, M. M., \& Guchait, P. (2009). Employees intent to leave: a comparison of determinants of intent to leave versus intent to stay. International Journal of Hospitality Management, 28, 374-381. doi: 10.1016/j.ijhm.2008.10.007

Choi, H.M., Mohammad, A.A.A. \& Kima, W.G. (2019). Understanding hotel frontline employees' emotional intelligence, emotional labor, job stress, coping strategies and burnout. International Journal of Hospitality Management, 82, 199-208

Choi, T. Y., \& Chu, R. (2001). Determinants of hotel guests' satisfaction and repeat patronage in the Hong Kong hotel industry. International Journal of Hospitality Management, 20(3), 277-297. 
Chuang, N. K. \& Lei, S. A. (2011). Job stress among casino hotel chefs in a top-tier tourism city. Journal of Hospitality Marketing \& Management, 20, 551-554

Clemes, M.D., Wu, H.C.J., Hu, B.D., \& Gan, C. (2009). An empirical study of behavioral intentions in the Taiwan hotel industry. Innovative Marketing, 5(3), 30-50.

Cleveland, J. N., O’Neill, J. W., Himelright, J. L., Harrison, M. M., Crouter, A. C., \& Drago, R. (2007). Work and family issues in the hospitality industry: Perspectives of entrants, managers, and spouses. Journal of Hospitality \& Tourism Research, 31(3), 275-298. doi:10.1177/1096348007299919

Conway, J. M. (1999). Distinguishing contextual performance from task performance for managerial jobs. Journal of applied Psychology, 84(1), 3-13. Dubinsky, A. J. \& Mattson, B. E. (1979). Consequences of role conflict and ambiguity experienced by retail salespeople. Journal of Retailing, 55(4), 70-86

Faucett, M. J., Corwyn, R. F. \& Poling T. H. (2013). Clergy role stress: Interactive effects of role ambiguity and role conflict on intrinsic job satisfaction. Pastoral Psychology, 62, 291-304.

Faulkner, B. \& Patiar, A. (1997). Workplace induced stress among operational staff in the hotel industry. International Journal of Hospitality Management, 16 (1), 99-117.

Fisher, C. D. \& Gitelson, R. (1983). A-meta analysis of the correlates of role conflict and ambiguity. Journal of Applied Psychology, 68(2), 320-333.

Fisher, C. D. (2003). Why do lay people believe that satisfaction and performance are correlated? Possible sources of a commonsense theory. Journal of Organizational Behavior, 24(6), 753-777.

Fisher, R. T. (2001). Role stress, the type A behavior pattern, and external auditor job satisfaction and performance. Behavioral Research in Accounting, 13(1), 143-170.

Fornell, C. \& Larkner, D. F. (1981). Evaluating structural equation models with unobservable variables and measurement error. Journal of Marketing Research, 18, 39-50.

Fried, Y., Ben-David, H. A., Tiegs, R. B., Avital, N. \& Yeverechyahu, U. (1998). The interactive effect of role conflict and role ambiguity on job performance. Journal of Occupational and Organizational Psychology, 71, 19-27.

Fried, Y., Shirom, A., Gilboa, S., \& Cooper, C. L. (2008). The mediating effects of job satisfaction and propensity to leave on role stress-job performance relationships: Combining meta-analysis and structural equation modeling. International Journal of Stress Management, 15(4), 305.

George, S. \& Weimerskirch, A. (1994). Total quality management: Strategies and techniques proven at today's most successful companies. New York: Wiley.

Gilboa, S., Shirom, A., Fried, Y., \& Cooper, C. (2008). A meta-analysis of work demand stressors and job performance: examining main and moderating effects. Personnel Psychology, 61(2), 227-272.

Gill, A. S., Flaschner, A. B., \& Shachar, M. (2006). Mitigating stress and burnout by implementing transformational leadership. International Journal of Contemporary Hospitality Management, 18(6), 469-481.

Goolsby, J. R. (1992). A theory of role stress in boundary spanning positions of marketing organizations. Journal of the Academy of Marketing Science, 20(2), 155-164.

Gordon, J. R. (1999). Organsiational behaviour: A diagnostic approach. New Jersey: Prentice Hall Inc.

Greene, C. N., \& Organ, D. W. (1973). An evaluation of causal models linking the received role with job satisfaction. Administrative Science Quarterly, 95-103.

Griffin, R. W. \& Moorhead, G. (1989). Organizational Behavior. Boston: Houghton Mifflin Company.

Grobelna, A. (2015). Role Ambiguity: A problem or a challenge facing contemporary hospitality industry. The critical role of employees' creatıvity. International Journal of Contemporary Management, 14(3), 77-98.
Grobelna, A., Sidorkiewicz, M., \& Tokarz-Kocik, A. (2016). Job satisfaction among hotel employees: analyzing selected antecedents and job outcomes. a case study from Poland. Argumenta Oeconomica 37(2), 281-310.

Gullahorn, J. T. (1956). Measuring role conflict. American Journal of Sociology, 61(4), 299-303.

Hackman, J. R., \& Oldham, G. R. (1975). Development of the job diagnostic survey. Journal of Applied Psychology, 60(2), 159.

Hair, J., Black, W., Babin, B. \& Anderson, R. (2010). Multivariate dato analysis (7th ed.). Upper Saddle River, NJ: Prentice-Hall.

Hight, S. K., \& Park, J. Y. (2019). Role stress and alcohol use on restaurant server's job satisfaction: Which comes first?. International Journal of Hospitality Management, 76, 231-239.

House, R. \& Rizzo, J. (1972). Role conflict and ambiguity as critical variables in a model of organizational behavior. Organizational Behavior and Human Performance, 7, 467-505.

House, R. J., Schuler, R. S. \& Levanoni, E. (1983). Role conflict and ambiguity scales: Reality or artifacts?. Journal of Applied Psychology, 68(2), 334-337.

Houtman, A., K. Jettinghoff, \& Cedillo, L. (2007). Raising awareness of stress at work in developing countries: A modern hazard in a traditional working environment: advice to employers and worker representatives. Protecting Workers' Health Series, No. 6. Geneva: World Health Organization.

Hsieh, A. T., \& Yen, C. H. (2005). The effect of customer participation on service providers' job stress. The Service Industries Journal, 25(7), 891-905.

Hu, H. H. S., \& Cheng, C. W. (2010). Job stress, coping strategies, and burnout among hotel industry supervisors in Taiwan. The International Journal of Human Resource Management, 21(8), 1337-1350.

Hu, M-L., Horng, J-S., \& Sun, Y-H. (2009). Hospitality teams: Knowledge sharing and service innovation performance. Tourism Management, 30(1), 41-50.

Hülsheger, U. R., Alberts, H. J., Feinholdt, A., \& Lang, J. W. (2013). Benefits of mindfulness at work: the role of mindfulness in emotion regulation, emotional exhaustion, and job satisfaction. Journal of Applied Psychology, 98(2), 310

Hwang, J., Lee, J. J., Park, S., Chang, H., \& Kim, S. S. (2014). The impact of occupational stress on employee's turnover intention in the luxury hotel segment. International Journal of Hospitality \& Tourism Administration, 15(1), 60-77. doi:10.1080/15256480.2014.872898

Indarti, S., Fernandes, A. A. R., \& Hakim, W. (2017). The effect of OCB in relationship between personality, organizational commitment and job satisfaction on performance. Journal of Management Development, 36(10), 1283-1293.

Jackson, S. E. and Schuler, R. S. (1985). A meta-analysis and conceptual critique of research on role ambiguity and role conflict in work settings. Organizational Behavior and Human Decision Processes, 36, 16-78.

Jankingthong, K. \& Rurkkhum, S. (2012), Factors affecting job performance: A review of literature. Silpakorn University Journal of Social Sciences, Humanities, and Arts, 12(2), 115-127.

Jogaratnam, G., \& Buchanan, P. (2004). Balancing the demands of school and work: stress and employed hospitality students. International Journal of Contemporary Hospitality Management, 16(4), 237-245. doi:10.1108/09596110410537397

Johnson, T. W. \& Stinson, J. E. (1975). Role ambiguity, role conflict and satisfaction: Moderating effects of individual differences. Journal of Applied Psychology, 60(3), 329-333.

Jones, E., Chonko, L., Rangarajan, D., \& Roberts, J. (2007). The role of overload on job attitudes, turnover intentions, and salesperson performance. Journal of Business Research, 60, 663-671. doi: 10.1016/j.jbusres.2007.02.014

Judge, T.A., Thoresen, C. J., Bono, J.E., \& Patton, G.K. (2001). The job satisfaction-job performance relationship: $A$ qualitative and quantitative review. Psychological Bulletin, 127, 376-407. 
June, S., \& Mahmood, R. (2020). Role ambiguity and job performance of employees in the service sector SMEs in Malaysia. Malaysian Management Journal, 15, 1-20.

Jung, H. S., \& Yoon, H. H. (2015). The impact of employees' positive psychological capital on job satisfaction and organizational citizenship behaviors in the hotel. International Journal of Contemporary Hospitality Management, 27(6), 1135-1156.

Kahn, R. L., Wolfe, D. M., Quinn, R. P., Snoek, J. D., \& Rosenthal, R. A. (1964). Organizational stress: Studies in role conflict and ambiguity. New York: Wiley

Karatepe, O.M. (2010). Role stress, emotional exhaustion, and job satisfaction in the hotel industry: The moderating role of supervisory support. FIU Hospital Review, 28(3), 48-66.

Karatepe, O. M. \& Ehsani, E. (2012). Work-related depression in frontline service jobs in the hospitality industry: Evidence from Iran. Journal of Human Resources in Hospitality \& Tourism, 11(1), 16-35.

Karatepe, O. M. \& Karatepe, T. (2010). Role stress, emotional exhaustion, and turnover intentions: Does organizational tenure in hotels matter?. Journal of Human Resources in Hospitality and Tourism, 9(1), 1-16.

Karatepe, O.M. \& Kılıç, H. (2009). The effects of two directions of conflict and facilitation on frontline employees' job outcomes. The Service Industries Journal, 29(7), 977-993.

Karatepe, O.M. \& Sokmen, A. (2006). The effects of work role and family role variables on psychological and behavioral outcomes of frontline employees. Tourism Management, 17(2), 255-268.

Karatepe, O.M., \& Uludag, O. (2008). Role stress, burnout and their effects on frontline hotel employees' job performance: Evidence from Northern Cyprus. International Journal of Tourism Research, 10(2), 111126.

Karatepe, O.M., Uludağ, O., Menevis, I., Hadzimehmedagic, L. \& Baddar, L. (2006). The effects of selected individual characteristicson frontline employee performance and job satisfaction. Tourism Management, 27(4), 547-560.

Karatepe, O.M., Uludağ, O., Menevis, İ., Hadzimehmedagic, L. \& Baddarc, L. (2006). The effects of selected individual characteristics on frontline employee performance and job satisfaction. Tourism Management, 27, 547-560.

Katz D. \& Kahn R. L. (1978). The Social Psychology of Organizations. New York: Wiley.

Kaya, I. (2010). Otel İşletmelerinde İş görenlerin İş Tatminini Etkileyen İşi Bırakma Eğilimi, Çukurova Üniversitesi. Sosyal Bilimler Enstitüsü Dergisi, 19(2), 219 - 236.

Keller, R. T. (1975). Role conflict and ambiguity: correlates with job satisfaction and values. Personnel Psychology, 28, 57-64.

Khuong, M. N., \& Yen, V. H. (2016). Investigate the effects of job stress on employee job performance - a case study at Dong Xuyen industrial zone, Vietnam. International Journal of Trade, Economics and Finance, $7(2), 31$.

Kim, B.C.P., Murrmann, S.K. \& Lee, G. (2009). Moderating effects of gender and organizational level between rolestress and job satisfaction among hotel employees. International Journal of Hospitality Management, 28, 612-619.

Kim, G., Ro, H., Hutchinson, J., \& Kwun, D. J. (2014). The effect of jaycustomer behaviors on employee job stress and job satisfaction. International Journal of Hospitality \& Tourism Administration, 15(4), 394-416.

Kim, W.G., Leong, J.K., Lee, Y.K. (2005). Effect of service orientation on job satisfaction, organizational commitment, and intention of leaving in a casual dinning chain restaurant. International Journal of Hospitality Management, 24(2), 171-193.

King, L. A., \& King, D. W. (1990). Role conflict and role ambiguity: A critical assessment of construct validity. Psychological Bulletin, 107(1), 48.
Kong, H., Jiang, X., Chan, W., \& Zhou, X. (2018). Job satisfaction research in the field of hospitality and tourism. International Journal of Contemporary Hospitality Management, 30(5), 2178-2194.

Kumar, P., Dass, M., \& Topaloglu, O. (2014). Understanding the drivers of job satisfaction of frontline service employees: Learning from "lost employees". Journal of Service Research, 17(4), 367-380.

Kuşluvan, S., Kuşluvan, Z., Ilhan, İ. \& Buyruk, L. (2010). The human dimension: A review of human resources management issues in the tourism and hospitality industry. Cornell Hospitality Quarterly, 51 (2): 171- 214.

Law, J., Pearce, P. L. \& Woods, B. A. (1995). Stress and coping in tourist attraction employees. Tourism Management, 16(4), 277-284.

Lee, J. J., \& Hwang, J. (2016). An emotional labor perspective on the relationship between customer orientation and job satisfaction. International Journal of Hospitality Management, 54, 139-150.

Li, X., Sanders, K., \& Frenkel, S. (2012). How leader-member exchange, work engagement and HRM consistency explain Chinese luxury hotel employees' job performance. International Journal Of Hospitality Management, 31(4), 1059-1066.

Lin, M., \& Ling, Q. (2018). Is role stress always harmful? Differentiating role overload and role ambiguity in the challenge-hindrance stressors framework. Tourism Management, 68, 355-366.

Machado, L. A. N., Junior, D. F. L. C., Mondo, T. S., Martins, E. S. \& Abreu, J. C. (2019). Strategic human resources management and hotel performance. Tourism \& Management Studies, 15(1), 65-79.

MacKinlay, K. (2003). Listening to people with dementia: A pastoral care perspective. Journal of Religious Gerontology, 13(3-4), 91-106.

Madera, J. M., Dawson, M., \& Guchait, P. (2016). Psychological diversity climate: justice, racioethnic minority status and job satisfaction. International Journal of Contemporary Hospitality Management, 28(11), 2514-2532.

Mei, AW. O., Dean, A.M., \& White, C.J. (1999). Analyzing service quality in the hospitality industry. Managing Service Quality, 9(2), 136-143.

Merton, R. K. (1957). The role set: Problems in sociological theory. The British Journal of Sociology, 8(2), 106-120.

Miles, R. H., \& Perreault, W. D. (1976). Organizational role conflict. Organizational Behavior and Human Performance, 17, 19-44.

Nicholson, P. J. \& Goh, S. C. (1983). The relationship of organization structure and interpersonal attitudes to role conflict and ambiguity in different work environments. Academy of Management Journal, 26(1), 148-155.

O'Neill, J.W. \& Davis, K. (2011). Work stress and well-being in the hotel industry. International Journal of Hospitality Management, 30(2), 385-390.

Park, J. K., Ahn, J., Han, S. L., Back, K. J., \& An, M. (2020). Exploring internal benefits of medical tourism facilitators' satisfaction: customer orientation, job satisfaction, and work performance. Journal of Healthcare Management, 65(2), 90-105.

Pizam, A., \& Thornburg, S. W. (2000). Absenteeism and voluntary turnover in Central Florida hotels: a pilot study. International Journal of Hospitality Management, 19(2), 211-217.

Pool, S. (1997). The Relationship of job satisfaction with substitutes of leadership, leadership behavior, and work motivation. The Journal of Psychology, 13(2), 271-283.

Ramos-Villagrasa, P. J., Barrada, J. R., Fernández-del-Río, E., \& Koopmans, L. (2019). Assessing job performance using brief self-report scales: The case of the individual work performance questionnaire. Journal of Work and Organizational Psychology, 35(3), 195-205.

Reetz, L. J. (1988). Conflict and stress among rural special educators. Rural Special Education Quarterly, 8(3), 22-26.

Riketta, M. (2008).The causal relation between job attitudes and performance: A meta-analysis of panel studies. Journal of Applied Psychology, 93, 472-481.

Rizzo, J. R., House, R. J. \& Lirtzman, S. I. (1970). Role conflict and ambiguity in complex organizations. Administrative Science Quarterly, 15(2), 150-163. 
Robbins, S.P. \& Judge, T.A. (2017). Organizational Behavior (17th Edition). Prentice Hall.

Rod, M., Carruthers, J., \& Ashill, N. (2006). Antecedents and outcomes of service recovery performance: insights from an organisation postcorporatisation and post deregulation. Innovative Marketing, 2(2), 20-31.

Rogers, D. L., \& Molnar, J. (1976). Organizational antecedents of role conflict and ambiguity in top-level administrators. Administrative Science Quarterly, 21(4), 598-610.

Ross, G. F. (1995). Work stress and personality measures among hospitality industry employees. International Journal of Contemporary Hospitality Management, 6, 9-13.

Ross, G.F. (1997). Career Stress Responses among Hospitality Employees. Annals of Tourism Research, 24(1), 41-51.

Ross, L.E. \& Boles, J.S. (1994). Exploring the influence of workplace relationships on work-related attitudes and behaviors in the hospitality work environment. International Journal of Hospitality Management, 13(2), 155-171.

Rotundo, M., \& Sackett, P. R. (2002). The relative importance of task, citizenship, and counterproductive performance to global ratings of job performance: A policy-capturing approach. Journal of Applied Psychology, 87(1), 66.

Rust, R.T., Stewart, G.L., Miller, H., \& Pielack, D. (1996). The satisfaction and retention of frontline employees: a customer satisfaction measurement approach. International Journal of Service Industry Management, 75(5), 62-80.

Saha, K., Reddy, M. D., Mattingly, S., Moskal, E., Sirigiri, A., \& De Choudhury, M. (2019). Libra: On linkedin based role ambiguity and its relationship with wellbeing and job performance. Proceedings of the ACM on Human-Computer Interaction, 3(CSCW), 1-30.

Sari, N. P. R., Bendesa, I. K. G., \& Antara, M. (2019). The influence of quality of work life on employees' performance with job satisfaction and work motivation as intervening variables in star-rated hotels in Ubud tourism area of Bali. Journal of Tourism and Hospitality Management, 7(1), 74-83.

Schuler, R. S. (1975). Role perceptions, satisfaction, and performance: A partial reconciliation. Journal of Applied Psychology, 60(6), 683-687.

Schuler, R. S., Aldag, R. J., \& Brief, A. P. (1977). Role conflict and ambiguity: A scale analysis. Organizational Behavior and Human Performance, 20(1), 111-128.

Shamim, S., Cang, S., \& Yu, H. (2017). Supervisory orientation, employee goal orientation, and knowledge management among front line hotel employees. International Journal of Hospitality Management, 62, 21-32.

Sheridan, J.E. \& Slocum, J.W. Jr (1975). The direction of the causal relationship between job satisfaction and work performance. Organizational Behavior and Human Performance, 14(2), 159-172.

Sieber, S. D. (1974). Toward a theory of role accumulation. American Sociological Review, 39, 567-578.

Siengthai, S., \& Pila-Ngarm, P. (2016). The interaction effect of job redesign and job satisfaction on employee performance. Evidencebased HRM, 4(2), 162-180.

Sönmez, S., Apostolopoulos, Y., Lemke, M. K., \& Hsieh, Y. J. (2020). Understanding the effects of COVID-19 on the health and safety of immigrant hospitality workers in the United States. Tourism Management Perspectives, 35, 100717. https://doi.org/10.1016/j.tmp.2020.100717

Spector, P.E. (1997). Job satisfaction: Application, assessment, causes, and consequences. Thousand Oaks, CA: Sage

Tabachnick, B. G., Fidell, L. S., \& Ullman, J. B. (2007). Using multivariate statistics. Boston, MA: Pearson.

Tameirão, D.C.M., \& Nunes, S. C. (2019). The feminisation of medical careers in Brazil and work-family conflict. Tourism \& Management Studies, 15(2), 2019, 47-55.

Tiyce, M., Hing, N., Cairncross, G., \& Breen, H. (2013). Employee stress and stressors in gambling and hospitality workplaces. Journal of Human Resources in Hospitality \& Tourism, 12(2), 126-154.
Tubre, C. \& Collins, J.M. (2000). Jackson and Schuler (1985) revisited: A meta-analysis of the relationships between role ambiguity, role conflict, and job performance. Journal of Management, 26(1), 155-169.

Üngüren, E. (2019). Determining the discrimination level of personality traits of frontline employees on job performances. Journal of Mehmet Akif Ersoy University Economics and Administrative Sciences Faculty, 6(3), 768-795.

Viswesvaran, C., \& Ones, D. S. (2000). Perspectives on models of job performance. International Journal of Selection and Assessment, 8(4), 216-226.

Walker Jr, O. C., Churchill Jr, G. A. \& Ford, N. M. (1975). Organizational determinants of the industrial salesman's role conflict and ambiguity. The Journal of Marketing, 39(1), 32-39.

Walsh, G. (2011). Unfriendly customers as a social stressor: An indirect antecedent of service employees' quitting intention. European Management Journal, 29, 67-78.

Wang, S., Zhang, X., \& Martocchio, J. (2011). Thinking outside of the box when the box is missing: Role ambiguity and its linkage to creativity. Creativity Research Journal, 23(3), 211-221.

Warriner, S., Hunter, L., \& Dymond, M. (2016). Mindfulness in maternity: Evaluation of a course for midwives. British Journal of Midwifery, 24(3), 188-195.

Weiss, H. M., \& Cropanzano, R. (1996). Affective events theory: a theoretical discussion of the structure, causes and consequences of affective experiences at work. Research in Organizational Behavior, 18, $1-74$.

Wu, C. H.-J., \& Liang, R.-D. (2009). Effect of experiential value on customer satisfaction with service encounters in luxury-hotel restaurants. International Journal of Hospitality Management, 28(4), 586-593.

Wu, G., Hu, Z., \& Zheng, J. (2019). Role stress, job burnout, and job performance in construction project managers: the moderating role of career calling. International Journal of Environmental Research and Public Health, 16(13), 2394.

Wu, H.C. \& Ko, Y.J (2013) Assessment of service quality in the hotel industry. Journal of Quality Assurance in Hospitality \& Tourism, 14(3), 218-244

Yang, J. T. (2010). Antecedents and consequences of job satisfaction in the hotel industry. International Journal of Hospitality Management, 29(4), 609-619.

Yang, Y., Zhang, H., \& Chen, X. (2020). Coronavirus pandemic and tourism: Dynamic stochastic general equilibrium modeling of infectious disease outbreak. Annals of Tourism Research, 83, 102913. https://doi.org/10.1016/j.annals.2020.102913

Yee, R. W., Yeung, A. C., \& Cheng, T. E. (2008). The impact of employee satisfaction on quality and profitability in high-contact service industries. Journal of Operations Management, 26(5), 651-668.

Yılmaz, Y., Üngüren, E., \& Kaçmaz, Y. Y. (2019). Determination of managers' attitudes towards eco-labeling applied in the context of sustainable tourism and evaluation of the effects of eco-labeling on accommodation enterprises. Sustainability, 11(18), 5069.

Yoon, M. H. \& Suh, J. (2003). Organizational citizenship behaviors and service quality as external effectiveness of contact employees. Journal of Business Research, 56(8), 597-611.

Young, C. A., \& Corsun, D. L. (2009). What a nuisance: Controlling for negative affectivity versus personality in hospitality stress research. International Journal of Hospitality Management, 28(2), 280-288.

Yun, S., Takeuchi, R., \& Liu, W. (2007). Employee self-enhancement motives and job performance behaviors: investigating the moderating effects of employee role ambiguity and managerial perceptions of employee commitment. The Journal of Applied Psychology, 92(3), 745756.

Zhou, Q., Martinez, L. F., Ferreira, A. I., \& Rodrigues, P. (2016). Supervisor support, role ambiguity and productivity associated with presenteeism: A longitudinal study. Journal of Business Research, 69(9), 3380-3387. 
Zohar, D. (1994). Analysis of job stress profile in the hotel industry. International Journal of Hospitality Management, 13(3), 219-231.

doi:10.1016/0278-4319(94)90022-1 